\title{
Managing the Dynamics of Group Projects in Higher Education: Best Practices Suggested by Empirical Research
}

\author{
Diane Fittipaldi \\ School of Business, St. Catherine University, United States
}

Received January 27, 2020; Revised April 17, 2020; Accepted April 27, 2020

Copyright $\bigcirc 2020$ by authors, all rights reserved. Authors agree that this article remains permanently open access under the terms of the Creative Commons Attribution License 4.0 International License

\begin{abstract}
Employers know the importance of teamwork and seek these skills when hiring and promoting staff. To address this need, universities include group projects in their curricula with the goal of developing employable graduates with experience collaborating in teams. Many studies exist on the value and importance of individual aspects of group work such as team size, selection methods and ways to prevent social loafing. However, when designing group projects, professors make a host of decisions across a wide range of project components. Only a few aging studies bring together the varied research on group projects into a comprehensive and practical whole. The goal of this study is to analyze results of empirical research studies highlighting the best practices on managing group activities in face-to-face higher education classrooms. This study used a semi-systematic approach to analyze over 46 peer reviewed empirical studies. A semi-systematic literature review approach allowed for the summarization of themes and patterns across a wide range of study types, research designs and student populations. The results of this synthesis involve ten themes which address the central decisions faculty face when designing and implementing group projects. Specifically this study uncovered a unique hybrid approach to purposely assemble teams, demonstrated the need to keep teams small, pointed out the importance of early and ongoing team training, showed the need for a team charter, determined the value a high level of professor engagement throughout the project, confirmed the benefit of formative and summative peer assessments, established the usefulness of conducting rater training, and pointed out the advantages for using electronic tools to aid team processes.
\end{abstract}

Keywords Group Projects, Team Projects, Social Loafing, Peer Assessments, Team Charters

\section{Introduction}

As businesses continue to gravitate toward team-oriented work, which requires collaboration and inter-personal skills, it comes as no surprise for employers to look for candidates with competencies in these areas [1,2]. A 2015 report by Hart Research and Associates [3] states that $83 \%$ of employers rate the ability to work effectively in teams as highly important. Business leaders know that teamwork enhances organizational results and feeds the bottom line [4-6].

Despite the need to prepare business students to effectively work in teams and teach them how to collaborate, undergraduate business and MBA programs often fall short when it comes to teaching these skills $[1,7,8]$. While curricula have increasingly included group projects as a way to mimic the demands of the workplace and develop students' abilities to work in teams, the effectiveness of these projects varies widely. For example, when administered well, group projects foster critical thinking, enhance problem-solving skills, encourage ownership, and increase collaboration [9-13]. However, when administered poorly, student achievement suffers and learning objectives goes unrealized [13-16].

The issues that accompany assigning students to work together on projects cause angst for professors and students alike. Professors struggle to balance the need to assess students individually and hold them accountable for their individual contributions, while at the same time fostering an atmosphere of collaboration and shared ownership over the project [17]. Students have objections. Their busy lives make it difficult to find a workable time to collaborate outside of class [17]. They also worry about their grades and whether a slacker in the group may hold their grade hostage[17].It follows that much research on group projects focuses on student satisfaction in an attempt to find ways to improve students' attitudes about these types 
of assignments. Student satisfaction increases, persistence increases, ultimately reducing attrition and improving retention [18]. Another important branch of the research conducted on group projects in higher education looks at ways to ensure the attainment of student learning outcomes, such as the critical soft skills necessary to work effectively in teams. Much of this scholarship spans decades of study.

However, the large body of research on group projects is fragmented. Studies typically offer singular insights into one aspect of these multi-faceted, complex projects. Some explore the best way to avoid social loafing, others analyze the best ways to formulate teams, and still others review the effect team size has on student learning. Due to the advent of advanced classroom technology such as online learning platforms, document sharing applications, and video conferencing, faculty and their students have a wide range of tools to assist with team collaboration. Because many of these tools are new, only a few studies exist to evaluate their use. As a result of this fragmentation, most studies offer implications for faculty piece by piece. Two studies, fielded over a decade ago, offer a synthesis of scholarship across different aspects of group work, providing professors with an overview of the effective methods[14,19]. However, research also shows that professors are either unaware of these best practices or ignore them, instead opting for a sink or swim approach [9, 20, 21].

In this paper, the author first reviewed the foundational scholarship, which set the stage for group work as it exists today. Next an analysis was conducted reviewing the most recent research on group projects used in higher education classrooms, primarily business classrooms. Four generalized themes emerged. First and most critical, is the importance of dedicated classroom instruction on team dynamics before group work begins. This includes the priority and diligence given to project design. The second theme pertains to the teams themselves, meaning team size, team formation techniques, and intragroup composition. The third theme involves methods for assessing team performance as well as individuals' contributions within the team. Here different evaluation methods come into play, including peer assessment techniques and self-assessment instruments. The last topic involves the tools used to improve collaboration and teamwork. This includes charters and diaries in addition to online project management tools used to assign tasks and keep track of deadlines. Each of these subtopics appears next. After each, a short discussion follows providing recommendations for practice. This article culminates with a summary of 10 best practices for faculty to consider when implementing group projects in higher education.

\section{Objective}

The purpose of this research is to analyze results of empirical research studies highlighting the best practices on managing group activities in face-to-face higher education classrooms. While many individual studies exist on various elements of group projects, few bring together these various components into a comprehensive whole. Among the few studies which summarize the body of scholarship on this topic, none have been published in the last ten years. Armed with an understanding of what the research tells us about which approaches have worked and which have not, faculty can use this synthesis as a guide for curriculum design and implementation.

\section{Materials and Methods}

\subsection{Conceptual Approach}

The task of synthesizing a large body of research on a topic serves to advance knowledge on that topic in a way that no single study can do alone. Synder[22]offers three conceptual approaches to this task: systematic, semi-systematic, and integrative approaches. Because the purpose of an integrative review is to critique the body of knowledge, this method fails to fit the objectives of this research. Instead, this study used the semi-systematic method for three reasons. First, semi-systematic reviews (unlike systematic reviews) work well for bodies of scholarship conducted across various disciplines by different groups of researchers [22]. Second, a semi-systematic approach allows for a synthesis "using meta-narratives instead of by measuring effect size," [22, p.335], which is often the aim of a systematic review. Last, a semi-systematic approach fits most directly with the research goal of this study, which aims to summarize the themes and patterns among the body of knowledge on group projects for use in practical application.

\subsection{Search Strategy}

The search strategy started with a selection of broad keywords such as "group projects" and "team projects" is combined with "higher education" to determine the breadth of available research on this topic. In total, this initial search spanned seven databases: Academic Search Premier, Business Source Premier, EBSCOhost MegaFile, Education Database, Gale Academic OneFile Select, ProQuest and Sage Journals Premier. The search returned 16 articles, which were reviewed in full to gain familiarity with the topic as a whole and to identify subtopics within. These subtopics were: methods of group formation, methods for assessing performance, issues and best practices. These led to a second round of keywords.

The second round included searches for the keywords social loafing, free riding, sink or swim, group size, peer evaluations, project diaries, and team charters. This round yielded 41 articles, all read in full to gain an understanding 
of the topic's complexity and nuance.

\subsection{Inclusion and Exclusion Criteria}

Papers that met the following criteria will be included in the final review:

- Studies from peer-reviewed journals

- Empirical studies

- Research studies involving implications for classroom application

- Research aimed at improving student satisfaction

- Research aimed at improving student learning outcomes

While studies involving business school students were prioritized, papers involving other disciplines were included as a way to triangulate learning across the board. Similarly, while the preponderance of the research involved in this synthesis was conducted in the United States, papers from the international community were included for the same reason. Two studies, one on team size and the other on team charters, offered insight into workplace teams and studied populations outside of higher education. These two studies confirmed findings conducted within higher education and were included in this synthesis.

Papers which fit the following criteria were eliminated from consideration:

- Articles from non-peer reviewed journals

- Research in K-12 settings

- Essays

- Reviews

Of the 57 articles reviewed, (16 from the original search and 41 from round two), 33 remained after applying the inclusion/exclusion criteria. To complete the data set, one last round of searching served to supplement areas where research was otherwise thin, for example team size and eTools. The final analysis included 46 studies.

\subsection{Data Abstraction Analysis}

All studies were reviewed in full and initially coded by topic as follows:

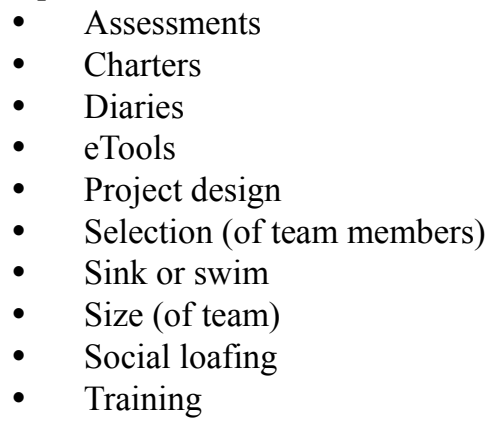

These initial codes were further synthesized and combined into four overarching areas based on application in the classroom. These four areas form the backbone of this analysis and the four tables included herein: team instruction and project design; team selection and size; team assessments; charters and electronic tools. The results of this research, outlined below, follow this structure. A brief discussion along with recommendations for practice follow each with a final summary of recommendations offered at the conclusion of this paper.

\section{Results}

\subsection{Team Instruction and Project Design}

Table 1 outlines the results of research related to team instruction and project design. A review of the literature reveals the most effective group projects begin with some forms of team training [12, 14, 23-25]. Yet, for a variety of reasons, most faculty, neglect to instruct students in this regard [26]. For example, professors report a lack of time and resources as a major concern. According to Murry \& Lonne[27],others feel they lack the knowledge and skills to teach team building. 
Table 1. Summary of Research on Team Instruction and Project Design

\begin{tabular}{|c|c|c|c|c|c|}
\hline Sub-Theme & Author(s) & Publication Date & Context & Research Method/Question & Findings \\
\hline \multirow{3}{*}{$\begin{array}{l}\text { Positive Effects of } \\
\text { Team Training }\end{array}$} & $\begin{array}{l}\text { S. Bailey, L. K. Barber } \\
\text { \& A. J. Ferguson [9] }\end{array}$ & 2015 & $\begin{array}{l}\text { Students in upper-level } \\
\text { psychology courses at a } \\
\text { Midwest university (USA) }\end{array}$ & $\begin{array}{l}\text { Attitudinal survey and statistical analysis to } \\
\text { measure students' perceptions of the effect } \\
\text { instructor involvement has on team projects }\end{array}$ & $\begin{array}{l}\text { Instructor involvement in group processes } \\
\text { was positively related to team cohesion, } \\
\text { communication, goal orientation and } \\
\text { planning. }\end{array}$ \\
\hline & $\begin{array}{l}\text { D. R. Bacon, K. A. } \\
\text { Stewart, \& S. W. } \\
\text { Silver, [14] }\end{array}$ & 1999 & $\begin{array}{l}\text { First year MBA students at a } \\
\text { Midwest university (USA) }\end{array}$ & $\begin{array}{l}\text { Attitudinal survey and statistical analysis to } \\
\text { measure students' perception of best/worst team } \\
\text { experiences }\end{array}$ & $\begin{array}{l}\text { Students perceive team experience is best } \\
\text { when the instructor provides training on } \\
\text { desired outcomes and processes. }\end{array}$ \\
\hline & $\begin{array}{l}\text { M. E. Burbach, G. S. } \\
\text { Matkin, K. M. } \\
\text { Gambrell, \& } \\
\text { H. E. Harding[23] }\end{array}$ & 2010 & $\begin{array}{l}\text { Undergraduate university } \\
\text { students across disciplines at a } \\
\text { Midwest university (USA) }\end{array}$ & $\begin{array}{l}\text { Statistical analysis of pre-post scores measuring } \\
\text { the effect year-long instructor training has on } \\
\text { student outcomes (knowledge, skills, abilities) }\end{array}$ & $\begin{array}{l}\text { Training had a significant impact on student } \\
\text { teamwork outcomes. }\end{array}$ \\
\hline \multirow{3}{*}{$\begin{array}{l}\text { Amount and Type } \\
\text { of Training }\end{array}$} & J. Cumming [28] & 2010 & $\begin{array}{l}2^{\text {nd }} \text { year undergraduate sports } \\
\text { and exercise science students at } \\
\text { a Southern university (USA) }\end{array}$ & $\begin{array}{l}\text { Attitudinal survey and statistical analysis to } \\
\text { measure students' perceptions of the } \\
\text { effectiveness of student-led instruction (Enquiry } \\
\text { Based Learning-EBL) in team dynamics }\end{array}$ & $\begin{array}{l}\text { Frequent use of group management strategies } \\
\text { was positively correlated with student } \\
\text { perceptions of group cohesion, effectiveness, } \\
\text { enjoyment and learning. } \\
\text { EBL was effective. }\end{array}$ \\
\hline & $\begin{array}{l}\text { L. Riebe, } \\
\text { D. Roepen, } \\
\text { B. Santarelli\& G. } \\
\text { Marchioro[29] }\end{array}$ & 2010 & $\begin{array}{l}\text { Undergraduate university } \\
\text { business students (Australia) }\end{array}$ & $\begin{array}{l}\text { Case study using an attitudinal survey to gauge } \\
\text { the impact of team training on student } \\
\text { satisfaction with team projects }\end{array}$ & $\begin{array}{l}\text { Teaching Tuchman's model improved } \\
\text { student awareness and contributed to } \\
\text { sustainable and transferable team skills. }\end{array}$ \\
\hline & $\begin{array}{l}\text { B. Scott-Ladd, \& C. C. } \\
\text { A. Chan }[35]\end{array}$ & 2008 & $\begin{array}{l}\text { 2nd year management students } \\
\text { at Universities in Australia and } \\
\text { Malaysia }\end{array}$ & $\begin{array}{l}\text { Attitudinal survey and statistical analysis to } \\
\text { assess the effect of team training on team conflict }\end{array}$ & $\begin{array}{l}\text { Training interventions helped students } \\
\text { manage conflict, improved teamwork and } \\
\text { improved learning satisfaction. }\end{array}$ \\
\hline \multirow{3}{*}{$\begin{array}{l}\text { Effect on Student } \\
\text { Satisfaction }\end{array}$} & $\begin{array}{l}\text { J. R. Tombaugh \& } \\
\text { C. O. Mayfield } \\
\text { [12] }\end{array}$ & 2014 & $\begin{array}{l}\text { MBA students enrolled in } \\
\text { teamwork course at a } \\
\text { Southwest university (USA) }\end{array}$ & $\begin{array}{l}\text { Content analysis of student responses to } \\
\text { open-ended question regarding team experiences }\end{array}$ & $\begin{array}{l}\text { Ten themes were identified for items such as } \\
\text { team communication, conflict management, } \\
\text { meeting management, planning, scheduling, } \\
\text { use of charters, relationship management. } \\
\text { Sharing these themes and offering instruction } \\
\text { on them enhanced the student experience. }\end{array}$ \\
\hline & $\begin{array}{l}\text { K. J. Chapman, \& S. } \\
\text { Van Auken, [24] }\end{array}$ & 2001 & $\begin{array}{l}\text { Undergraduate } \\
\text { students across } 32 \text { acadiness } \\
\text { institutions (USA) }\end{array}$ & $\begin{array}{l}\text { Attitudinal survey and statistical analysis to } \\
\text { measure students' attitudes toward group projects }\end{array}$ & $\begin{array}{l}\text { Instructors who operate as positive, proactive } \\
\text { agents on behalf of group work improved } \\
\text { students' attitudes toward group work. } \\
\text { Instructors who discuss group logistics and } \\
\text { dynamics had positive effect on student } \\
\text { attitudes toward group work. }\end{array}$ \\
\hline & E. Kapp [25] & 2009 & $\begin{array}{l}4^{\text {th }} \text { year undergraduate students } \\
\text { in an occupational safety course } \\
\text { at a Midwest university (USA) }\end{array}$ & $\begin{array}{l}\text { Statistical analysis of course evaluations and } \\
\text { student perceptions in sections with team } \\
\text { building intervention vs. control (no intervention) }\end{array}$ & $\begin{array}{l}\text { Team building intervention outperformed } \\
\text { control on all measures. }\end{array}$ \\
\hline
\end{tabular}


Table 1 Continued

\begin{tabular}{|c|c|c|c|c|c|}
\hline \multirow{3}{*}{ Project Design } & $\begin{array}{l}\text { A. L. Parsons, \& E. } \\
\text { Lepkowska-White } \\
\text { [32] }\end{array}$ & 2009 & $\begin{array}{l}2^{\text {nd }}-4^{\text {th }} \text { year undergraduate } \\
\text { marketing students at a } \\
\text { Northeast liberal arts college } \\
\text { (USA) }\end{array}$ & $\begin{array}{l}\text { Attitudinal survey and statistical analysis } \\
\text { comparing students' perceptions of project work } \\
\text { for clients vs. hypothetical companies }\end{array}$ & $\begin{array}{l}\text { Students rated theoretical projects and real } \\
\text { client projects equally on most dimensions. } \\
\text { Motivation, the development of teamwork } \\
\text { and interpersonal skills were significantly } \\
\text { higher for theoretical projects. }\end{array}$ \\
\hline & C.M. Wood [33] & 2003 & $\begin{array}{l}\text { Undergraduate marketing } \\
\text { students at a Midwest university } \\
\text { (USA) }\end{array}$ & $\begin{array}{l}\text { Control vs. test methodology to measure the } \\
\text { effect student ownership has on student } \\
\text { satisfaction with group projects }\end{array}$ & $\begin{array}{l}\text { Students perceived group projects where they } \\
\text { had a degree of ownership to be better at } \\
\text { promoting learning. } \\
\text { Psychological ownership was enhanced when } \\
\text { students had input into the project design. }\end{array}$ \\
\hline & $\begin{array}{l}\text { C. J. Ferrante, S. G. } \\
\text { Green, \& W. R. Forster } \\
\text { [34] }\end{array}$ & 2006 & $\begin{array}{lr}\text { Undergraduate } & \text { management } \\
\text { students at } & \text { an } \\
\text { AACSB-accredited } & \text { university } \\
\text { (USA) } & \end{array}$ & $\begin{array}{l}\text { Test vs. control design to determine if teams with } \\
\text { incentivized leaders outperform teams without a } \\
\text { formal leader }\end{array}$ & $\begin{array}{l}\text { Teams with incentivized leaders performed } \\
\text { significantly better than control on } \\
\text { dimensions of social loafing, interactional } \\
\text { justice, procedural justice, leader } \\
\text { responsibility and accountability. }\end{array}$ \\
\hline
\end{tabular}


However, the literature offers clear guidance on the benefits of team training, both in terms of professor-led activities as well as enquiry-based learning (EBL), which is student initiated [28]. Taking the time to instruct students in the fundamentals of team dynamics improves team processes, enhances student satisfaction, both of which have a positive effect on team performance and student learning outcomes [12, 14, 23-25]. The type of training method varied by study, Kapp [25]used a test versus control methodology to show the effectiveness of dedicating one class period to team building at the onset of the project before group work began. The process included a short lecture and a series of teambuilding exercises in which students examined their individual management styles. Students also completed an exercise in developing a team charter. Teaching students about Tuckman's theory on the four stages of team development resulted in a high degree (93\%) of student satisfaction [29]. Scott-Ladd \& Chan [30] showed that team instruction of no more than ten minutes in each of five class periods prior to the formation of student groups improved productivity. Lastly, Cumming[28] confirmed a similar link between student-initiated training and satisfaction with the team experience. The author asserted student-led training instilled a sense of ownership over team processes, furthering students' commitment and motivation. Here, student groups negotiated the best ways to work by using open-ended questions provided by the instructor.

Without explicit training of some kind, professors risk project success and jeopardize student satisfaction. Students come to group work with a range of team management skills and differing expectations regarding how they should operate [31]. Training assures alignment and helps calibrate expectations, both of which facilitate goal attainment and group achievement

Outside of the need for initial training, the literature shows that professor involvement throughout the process improves student satisfaction and performance [9]. For example, when a professor becomes a "more positive proactive agent on behalf of group work" [24, p.121], students' attitudes toward group work improves and their belief in the value of this type of learning is advanced. Similarly, Bailey[9] found when instructors communicate the rationale for and benefits of working in groups, team cohesion increases. The same research found when instructors provide ongoing advice and help students resolve group dysfunction, team dynamics improve.

The design of group projects takes many forms. Some focus on the issues and problems of real-world situations, often in the form of client-based projects, while others use theoretical or hypothetical scenarios. Professors often assume real-life experiences enhance students' motivation, which fosters greater student satisfaction and better outcomes[32]. On the contrary Parsons \& Lepkowska-White, [32] showed both types of projects work equally well as measured on a variety of dimensions.
For example, students felt both methods offered superior learning opportunities when compared to other forms of instruction. There were no significant differences in the students' perception of realism nor in the project's contribution to the students' skill development and learning of the subject matter. When taken together with the work of Wood [33], the key to project design seems to lie in assuring students feel a sense of ownership over the project, which often comes from involving them in the early phases of project development.

Unlike real world work teams, student teams operate as collaboration among equals without the benefit of an official team leader. If a leader emerges, she/he may have responsibility for project delivery but typically holds no authority over team members. In these situations, project leaders also operate without the ability to apply performance incentives or rewards, which are often present in real-world work. Ferrante, Green \& Forster [34] tested a project design, which used an incentive system for team leaders along with downstream incentives for team members. These reward systems were meant to replicate the way team leaders and team members that are rewarded in real-world, on-the-job projects. In this research, the incentive structure proved effective. Specifically, the project grade included two components: base points (equivalent to base pay in the work world) awarded for the quality of the project and incentive points (equivalent to bonus pay). Professors awarded incentive points to the team leader if the quality of the group's project proved exceptional. The leader's grade was calculated as the sum of both (base points + incentive points). To further mimic the real world, professors empowered the team leader with the responsibility of awarding incentive points to each team member based on each individual's contribution to the project. This unique project design and grading system significantly outperformed the control, which employed no such incentives. The authors reported a decrease in free riding and a significant increase in students' perception of inter-actional and procedural justice.

\subsection{Discussion on Team Instruction and Project Design}

Faculty commonly uses a sink or swim approach to implement group projects [23-25] and then deal with the aftermath of student dissatisfaction or spend time resolving conflicts due to social loafing and other issues. From the body of research reviewed here, a preponderance of evidence supports the value of initial as well as on-going team training to prevent issues like these from arising throughout the project. Professors' goals in assigning team projects include helping their students learn how to collaborate effectively and to acquire the soft skills employers seek. To do this, three recommendations emerge from the literature on the topic of training.

First, include team training at the onset of the project. Dedicating as little as one class session to team building 
instruction showed improvement in student satisfaction and performance[25].Training might include exercises or lecture materials on the stages of team development, how to communicate in teams, goal setting, building consensus, conflict resolution, setting expectations, and roles and responsibilities.

Second, professors need to continue to signal their commitment to each team's success, not only at the beginning but throughout the duration of the assignment. This can take several forms. For example, professors can reinforce the value and importance of group work. They can demonstrate their championship for the process as well as help students resolve conflicts. Taking these steps improves team dynamics and students' satisfaction with their experience [9].

Third, while training students early in the process is key, research also shows that intermittent classroom discussions on team dynamics and/ or training along the way improve performance [24]. Setting aside 20-30 minutes for one or two full-class brief discussions from time to time adds to and reinforces the training students received early on, ultimately buoying students' attitudes toward their experience and the team process overall.

\subsection{Team Selection and Size}

Generally, teams come together because students self-select their teammates or professors randomly or purposefully assemble them into teams. Commonly, faculty rely on self-selection, in part because they believe students favor this method [35].Both selection methods offer advantages and disadvantages. Table 2 summarizes the body of knowledge on this topic covering both team selection and team size.

Research indicates students are partial to selecting their own teams and that doing so holds several advantages. In the majority of the studies on team selection presented in Table 2, results show self-selected teams experience a smoother process and more productive working relationships. 
Table 2. Team Size and Selection

\begin{tabular}{|c|c|c|c|c|c|}
\hline Sub-Theme & Author(s) & Publication Date & Context & Research Method/Question & Findings \\
\hline $\begin{array}{l}\text { Positive Effects of } \\
\text { Self-Selection }\end{array}$ & $\begin{array}{l}\text { D. R. Bacon, } \\
\text { K. A. Stewart \& S. W. } \\
\text { Silver [14] }\end{array}$ & 1999 & 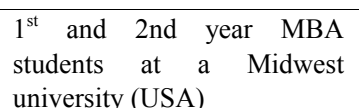 & $\begin{array}{l}\text { Attitudinal survey and statistical analysis to } \\
\text { measure students' perceptions self and } \\
\text { randomly assigned teams }\end{array}$ & $\begin{array}{l}\text { Self-selection is associated with "best" team } \\
\text { experiences and with "improved team processes." }\end{array}$ \\
\hline \multirow{4}{*}{$\begin{array}{l}\text { Positive Effects of } \\
\text { Self-Selection } \\
\text { Positive }\end{array}$} & $\begin{array}{l}\text { K. J. Chapman, M. } \\
\text { Meuter, } \\
\text { D. Toy \& } \\
\text { L. Wright [15] }\end{array}$ & 2006 & $\begin{array}{l}\text { Marketing students at } \\
\text { AACSB accredited program } \\
\text { at a Western university } \\
\text { (USA) }\end{array}$ & $\begin{array}{l}\text { Attitudinal survey and statistical analysis to } \\
\text { measure outcomes and students' perception } \\
\text { of self-selected and randomly selected } \\
\text { teams }\end{array}$ & $\begin{array}{l}\text { Self-selected groups had better results on a variety } \\
\text { of outcomes and processes, including } \\
\text { communication, enthusiasm, confidence in other } \\
\text { team members, ability to resolve conflict, reduction } \\
\text { in social loafing. }\end{array}$ \\
\hline & $\begin{array}{l}\text { S. Hilton, \& F. Phillips } \\
\text { [36] }\end{array}$ & 2010 & $\begin{array}{l}\text { Introductory } \\
\text { students at a accounting } \\
\text { university }\end{array}$ & $\begin{array}{l}\text { Grounded theory qualitative analysis to } \\
\text { determine students' experiences with } \\
\text { student selected vs. professor selected } \\
\text { groups }\end{array}$ & $\begin{array}{l}\text { Student selected groups had more social cohesion, } \\
\text { began work more quickly and reported more even } \\
\text { distribution of workload. }\end{array}$ \\
\hline & $\begin{array}{l}\text { S. Mahenthiran, \& P. J. } \\
\text { Rouse [45] }\end{array}$ & 2000 & $\begin{array}{l}\text { Students in an introductory } \\
\text { accounting class at a Midwest } \\
\text { university (USA) }\end{array}$ & $\begin{array}{l}\text { Attitudinal survey and statistical analysis to } \\
\text { measure student perceptions and } \\
\text { satisfaction of self and randomly selected } \\
\text { teams }\end{array}$ & $\begin{array}{l}\text { Group performance and satisfaction was greater in } \\
\text { teams where pairs of friends were assigned } \\
\text { compared to teams with students randomly } \\
\text { assigned. }\end{array}$ \\
\hline & $\begin{array}{l}\text { M.L. Connerley\& } \\
\text { F. A. Mael[69] }\end{array}$ & 2001 & $\begin{array}{l}\text { Undergraduate human } \\
\text { resource management and } \\
\text { organizational behavior } \\
\text { students at a Southeast and } \\
\text { Northeast university (USA) }\end{array}$ & $\begin{array}{l}\text { Attitudinal survey and statistical analysis to } \\
\text { determine student perceptions of team } \\
\text { selection }\end{array}$ & $\begin{array}{l}\text { Self-selected teams were more satisfied with their } \\
\text { performance }\end{array}$ \\
\hline \multirow[b]{2}{*}{$\begin{array}{l}\text { Faculty Engineered } \\
\text { Groups }\end{array}$} & $\begin{array}{l}\text { M. Huxham\& R. Land } \\
\text { [41] }\end{array}$ & 2000 & $\begin{array}{l}1^{\text {st }} \text { year university biology } \\
\text { students (United Kingdom) }\end{array}$ & $\begin{array}{l}\text { Statistical analysis comparing the } \\
\text { performance of randomly vs. purposefully } \\
\text { formed groups }\end{array}$ & $\begin{array}{l}\text { Students from both types of teams preferred } \\
\text { self-selection. } \\
\text { Both types of teams performed similarly. }\end{array}$ \\
\hline & $\begin{array}{l}\text { N. M. Schullery } \\
\& \\
\text { S. E. Schullery[40] }\end{array}$ & 2006 & $\begin{array}{l}\text { Junior and senior } \\
\text { undergraduate students in } \\
\text { business courses at a Midwest } \\
\text { university (USA) }\end{array}$ & $\begin{array}{l}\text { Rank-order correlation analysis used to } \\
\text { determine degree to which group } \\
\text { homo/heterogeneity (based on Myer's } \\
\text { Briggs profile) is associated with group } \\
\text { advantages or disadvantages for students }\end{array}$ & $\begin{array}{l}\text { Shyness was mitigated in homogeneous groups and } \\
\text { students earned higher grades on the group project. } \\
\text { Heterogeneity promoted better debates, presentation } \\
\text { of thought, and skill levels. } \\
\text { Women benefit from heterogeneous groups and men } \\
\text { from homogeneous groups. }\end{array}$ \\
\hline
\end{tabular}


Table 2 Continued

\begin{tabular}{|c|c|c|c|c|c|}
\hline \multirow{5}{*}{$\begin{array}{l}\text { Team Composition's } \\
\text { Effect } \quad \text { on } \\
\text { Achievement }\end{array}$} & $\begin{array}{l}\text { R. Seethamraju, \& M. } \\
\text { Borman [35] }\end{array}$ & 2009 & $\begin{array}{l}\text { Post graduate business } \\
\text { students in information } \\
\text { systems class at an Australian } \\
\text { university }\end{array}$ & $\begin{array}{l}\text { Focus groups and attitudinal survey to } \\
\text { understand student group formation } \\
\text { processes. Academic performance } \\
\text { measured via a graded assignment }\end{array}$ & $\begin{array}{l}\text { Students consider a range of components when } \\
\text { forming groups: convenience, skills, social cohesion } \\
\text { and task management. } \\
\text { Teams with strong skills/knowledge, social } \\
\text { cohesion and task management perform best. } \\
\text { Self or instructor formation may not matter as long } \\
\text { as team has strong skills, cohesion and task } \\
\text { management }\end{array}$ \\
\hline & $\begin{array}{l}\text { S. Hilton, \& F. Phillips } \\
\text { [36] }\end{array}$ & 2010 & $\begin{array}{l}\text { Introductory } \\
\begin{array}{l}\text { accounting } \\
\text { students at a } \\
\text { university }\end{array}\end{array}$ & $\begin{array}{l}\text { Grounded theory qualitative analysis to } \\
\text { determine students' experiences with } \\
\text { student selected vs. professor selected } \\
\text { groups }\end{array}$ & $\begin{array}{l}\text { Group formation had no impact on achievement. } \\
\text { Group achievement corresponded with individual } \\
\text { student competencies. }\end{array}$ \\
\hline & $\begin{array}{l}\text { M. C. Dyball, A. Reid, } \\
\text { P. Ross \& H. Schoch } \\
\text { [37] }\end{array}$ & 2006 & $\begin{array}{lr}\text { Undergraduate } & \text { university } \\
\text { accounting } & \text { students } \\
\text { (Australia) } & \end{array}$ & $\begin{array}{l}\text { Attitudinal survey and statistical analysis to } \\
\text { determine students' perceptions about } \\
\text { group work }\end{array}$ & $\begin{array}{l}\text { Among one sample, self-selected and } \\
\text { professor-selected teams performed similarly. } \\
\text { Among another sample, self-selection yielded } \\
\text { weaker performance. }\end{array}$ \\
\hline & $\begin{array}{l}\text { J. Van der Laan Smith } \\
\text { \& R. M. Spindle [38] }\end{array}$ & 2007 & $\begin{array}{l}2^{\text {nd }} \text { year accounting students } \\
\text { at a Southeast university } \\
\text { (USA) }\end{array}$ & $\begin{array}{l}\text { Attitudinal survey and statistical analysis to } \\
\text { measure student perceptions of } \\
\text { instructor-formed } \quad \text { groups and } \\
\text { student-selected groups }\end{array}$ & $\begin{array}{l}\text { Instructor-formed groups did not enhance individual } \\
\text { student learning as measured by performance } \\
\text { outcomes. } \\
\text { In groups with high-performing students, } \\
\text { student-formed groups enhanced individual learning } \\
\text { Students perceived self-selected groups to be more } \\
\text { conducive to individual learning }\end{array}$ \\
\hline & $\begin{array}{l}\text { S. Wang \& } \\
\text { S. J. Lin [39] }\end{array}$ & 2007 & $\begin{array}{l}\text { Undergraduate university } \\
\text { students in introductory } \\
\text { psychology course (Taiwan) }\end{array}$ & $\begin{array}{l}\text { Qualitative and quantitative analysis to } \\
\text { assess the effect of self-efficacy on group } \\
\text { performance }\end{array}$ & $\begin{array}{l}\text { Grouping students according to degree of individual } \\
\text { self-efficacy did not correlate with strong group } \\
\text { performance. } \\
\text { Grouping students according to degree of collective } \\
\text { (total group) efficacy correlated with strong group } \\
\text { performance. }\end{array}$ \\
\hline \multirow{3}{*}{ Team Size } & $\begin{array}{l}\text { A. C. North, P. A. } \\
\text { Linley \& } \\
\text { D.J. Hargreaves [42] }\end{array}$ & 2000 & $\begin{array}{l}1^{\text {st }} \text { year university psychology } \\
\text { students (United Kingdom) }\end{array}$ & $\begin{array}{l}\text { Statistical analysis to determine the output } \\
\text { and productivity of different team sizes }\end{array}$ & $\begin{array}{l}\text { Smaller ( } 3 \text { members) groups were more productive } \\
\text { than larger ( } 8 \text { members) groups }\end{array}$ \\
\hline & $\begin{array}{l}\text { P. Aggarwal \& C. L. } \\
\text { O'Brien [43] }\end{array}$ & 2008 & $\begin{array}{l}\text { Junior and senior } \\
\text { undergraduate students in } \\
\text { business courses at a Midwest } \\
\text { university (USA) } \\
\end{array}$ & $\begin{array}{l}\text { Attitudinal survey and statistical analysis to } \\
\text { measure students' perceptions of team } \\
\text { experience }\end{array}$ & $\begin{array}{l}\text { Big groups experienced more social loafing. } \\
\text { Team selection method (self vs. instructor-formed) } \\
\text { did not impact incidence of social loafing }\end{array}$ \\
\hline & $\begin{array}{l}\text { M. Sharma \& A. Ghosh } \\
\text { [44] }\end{array}$ & 2007 & $\begin{array}{l}\text { Workers in information } \\
\text { technology companies in } \\
\text { India }\end{array}$ & $\begin{array}{l}\text { Statistical analysis to compare performance } \\
\text { of different size teams }\end{array}$ & $\begin{array}{l}\text { Small ( } 3-4 \text { members) and medium sized teams (5-7 } \\
\text { members) performed better than large teams (8-14 } \\
\text { members) }\end{array}$ \\
\hline
\end{tabular}


Specifically, they have greater social cohesion, fewer incidences of conflict, better communication, higher confidence, and a more even distribution of workload [15, 36]. Despite student attitudes toward self-selection and the potential advantages to intrateam dynamics, the research is mixed on how well self-selected teams perform in terms of outcomes. As measured by the quality of the teams' output, the method of team formation may not matter [35-37]. Instead, the research points to the strengths and aptitudes of individual contributors as the factors that most directly influence team performance. For example, student learning increases when there is at least one high-performing student on the team [38]. Similarly, group achievement is positively correlated with the strength of the individual competencies of individual team members [35]. Thus, self or instructor-formed groups may not matter so long as at least some of the team members possess strong domain knowledge and task management skills $[35,36]$. In a similar vein, Wang \&Lin [39] asserted that self-efficacy is a key ingredient to group achievement, which again acts independently of group formation techniques.

Given the research on the importance of the quality of a team's composition, the question remains whether professors should engineer teams in an attempt to account for such factors as subject matter expertise and team leadership skills. Schullery \& Schullery[40] assembled teams using Myers Briggs profiles in an attempt to determine if heterogeneity vs. homogeneity enhanced team processes. The results showed advantages and disadvantages to both types of teams, falling short of conclusive or practical implications. Huxham and Land [41] used the Honey and Mumford learning styles questionnaire to assemble teams with complementary skills. However, the authors found no significant differences in performance between the professor-assembled teams and self-selected teams. It follows that engineering team composition takes time and deliberation but may not yield desired results.

On the topic of team size, the research points to wide agreement. Small teams outperform large ones. The research supports keeping teams to four or five members [42]. Small teams have fewer free riders, lower incidence of conflict and on the whole perform better [30, 43, 44]. In contrast, larger teams can form subgroups, causing disruptions, leading to dysfunction[44].

\subsection{Discussion on Team Selection and Size}

The method of team selection is one of the first decisions professors make when including group projects in their courses. Much debate exists among faculty on the merits of self-selected vs. professor-assigned teams. This review of the relevant research on team selection helps professors with this debate.

Self-selected teams start out with the advantage of social cohesion, a key ingredient in preventing conflict and improving communication. However, the quality of the team's output often relies on measures outside of student preferences for working with their friends. The research indicates the quality of the team's output correlates with the individual skills and competencies of individual students on the team. Taking a binary approach (self vs. professor selection) limits the possibilities. Taking a hybrid approach to forming student teams, similar to the methodology used by Mahenthiran, \& Rouse [45] whooffer a solution worthy of consideration. Here students selected a class member with whom they wished to work, essentially submitting a "pair" request to the professor. Professors then assembled teams by combining pairs of students to work together in teams of four. By following this method, faculty can review the competencies of the pairs and engineer teams to assure each group has individuals with strengths in the areas of team leadership, domain knowledge and self-efficacy. At the same time, this gives students the satisfaction of working with self-selected teammates.

Lastly, research confirms small teams (4 people) perform better than large teams, in part because they experience a lesser degree of social loafing [42, 46]. Moreover, the need for professor intervention to resolve conflicts decreases with team size, particularly in teams of four or five $[13,30]$. To the extent possible, professors should set team size at four students as a goal and adjust as needed based on the factors outlined above.

\subsection{Team Assessments}

In assessing team projects, faculty needs to certify not only the group's overall achievement but also formative learning [47]. While both are important, only formative assessments facilitate mastery of team skills [46, 47]. Professors face one additional challenge when assessing group projects and that is isolating and measuring individual contributions among the team members. Peer evaluations can help and have proven to be valuable in terms of accuracy and reliability [46-49].

Table 3 outlines the research on the use of formative assessments (peer reviews) and their relation to social loafing. This body of scholarship supports the use of peer reviews. 
Table 3. Research on Team Assessment

\begin{tabular}{|c|c|c|c|c|c|}
\hline Sub-Theme & Author(s) & $\begin{array}{l}\text { Publication } \\
\text { Date }\end{array}$ & Context & Research Method/Question & Findings \\
\hline \multirow[t]{2}{*}{ Reliability, Validity } & D. F. Baker [46] & 2007 & $\begin{array}{l}2^{\text {nd }} \text { and } 3^{\text {rd }} \text { year business students at } \\
\text { private Southern college (USA) }\end{array}$ & $\begin{array}{l}\text { Attitudinal survey and statistical } \\
\text { analysis to assess relative value of } \\
\text { long form, short form and points } \\
\text { allocation methods of peer } \\
\text { evaluation }\end{array}$ & $\begin{array}{l}\text { All three methods were reliable and related to } \\
\text { individual performance. } \\
\text { Short form and long form performed similarly } \\
\text { for reliability, individual performance and } \\
\text { grade outcomes. }\end{array}$ \\
\hline & $\begin{array}{l}\text { B. Zhang, L. Johnson, \& } \\
\text { G. B. Kelik[49] }\end{array}$ & 2008 & $\begin{array}{l}\text { Undergraduate university teacher } \\
\text { education students (New Zealand) }\end{array}$ & $\begin{array}{l}\text { Statistical analysis to test the } \\
\text { reliability and validity of peer and } \\
\text { self-ratings in group work }\end{array}$ & $\begin{array}{l}\text { Despite training and rubric, evaluations } \\
\text { showed both a group effect and a rater effect. }\end{array}$ \\
\hline \multirow{4}{*}{$\begin{array}{l}\text { Effects of Team } \\
\text { Assessment }\end{array}$} & E. Kapp [25] & 2009 & $\begin{array}{l}4^{\text {th }} \text { year undergraduate students in an } \\
\text { occupational safety course at a Midwest } \\
\text { university (USA) }\end{array}$ & $\begin{array}{l}\text { Statistical analysis of course } \\
\text { evaluations and student perceptions } \\
\text { in test vs. control }\end{array}$ & $\begin{array}{l}\text { Peer evaluation ( } 3 \text { readings throughout the } \\
\text { project). Students used the feedback to } \\
\text { assess/alter behavior vis a vis team standards. }\end{array}$ \\
\hline & $\begin{array}{l}\text { P. Aggarwal \& C. L. } \\
\text { O’Brien [43] }\end{array}$ & 2008 & $\begin{array}{l}\text { Junior and senior undergraduate students } \\
\text { enrolled in business courses at a Midwest } \\
\text { university (USA) }\end{array}$ & $\begin{array}{l}\text { Attitudinal survey and statistical } \\
\text { analysis to measure students' } \\
\text { perceptions of team experience }\end{array}$ & $\begin{array}{l}\text { Peer evaluations reduced social loafing. } \\
\text { As the frequency of peer evaluations } \\
\text { increased, the incidence of social loafing } \\
\text { decreased. }\end{array}$ \\
\hline & P. D. Rafferty [50] & 2012 & $\begin{array}{l}\text { Part-time MBA students at a private, } \\
\text { co-educational Eastern university (USA) }\end{array}$ & $\begin{array}{l}\text { Single case embedded study to } \\
\text { understand student perceptions of } \\
\text { peer evaluation process }\end{array}$ & $\begin{array}{l}\text { Students do not regard peer evaluations as } \\
\text { effective for themselves. Students view peer } \\
\text { evaluations as an aid for the professor }\end{array}$ \\
\hline & $\begin{array}{l}\text { C. M. Brooks, \& } \\
\text { J. L. Ammons [52] }\end{array}$ & 2003 & $\begin{array}{l}\text { Business students in introductory } \\
\text { business class at private Northeast } \\
\text { university (USA) }\end{array}$ & $\begin{array}{l}\text { Statistical analysis on self and peer } \\
\text { assessment tools to determine the } \\
\text { effect on social loafing }\end{array}$ & $\begin{array}{l}\text { Social loafing was reduced when evaluations } \\
\text { were conducted early and several times during } \\
\text { the course of the project. }\end{array}$ \\
\hline \multirow{3}{*}{$\begin{array}{l}\text { Style and Type of } \\
\text { Assessment }\end{array}$} & G.L. May [51] & 2008 & $\begin{array}{l}\text { Upper level undergraduate business } \\
\text { students in Southeast university (USA) }\end{array}$ & $\begin{array}{l}\text { Quasi-experiment with control vs. } \\
\text { test with test cell receiving rater } \\
\text { training. Multivariate analysis to } \\
\text { determine subgroup differences } \\
\text { based on } 4 \text { social styles }\end{array}$ & $\begin{array}{l}\text { Peer evaluation scores did not differ by } \\
\text { student social style. } \\
\text { Rater training reduced rater bias. }\end{array}$ \\
\hline & D. F. Baker [46] & 2007 & $\begin{array}{l}2^{\text {nd }} \text { and } 3^{\text {rd }} \text { year business students at } \\
\text { private Southern college (USA) }\end{array}$ & $\begin{array}{l}\text { Attitudinal survey and statistical } \\
\text { analysis to assess relative value of } \\
\text { long form, short form and points } \\
\text { allocation methods of peer } \\
\text { evaluation }\end{array}$ & $\begin{array}{l}\text { Short form and long form performed similarly } \\
\text { on individual performance and grade } \\
\text { outcomes. } \\
\text { Long form was superior for individual student } \\
\text { developmental purposes. }\end{array}$ \\
\hline & $\begin{array}{l}\text { B. Zhang \& } \\
\text { M. Ohland[54] }\end{array}$ & 2009 & $\begin{array}{l}\text { Undergraduate management students at a } \\
\text { Southeast university (USA) }\end{array}$ & $\begin{array}{l}\text { Statistical analysis to assess the } \\
\text { relative value of four different } \\
\text { methods for measuring individual } \\
\text { contributions to group work }\end{array}$ & $\begin{array}{l}\text { Adjusting scores to reflect individual } \\
\text { contributions had merit. } \\
\text { Rating team members by comparing } \\
\text { contributions within groups and between } \\
\text { groups both had advantages and were less } \\
\text { sensitive to group size. } \\
\text { Data supported the use of the between group } \\
\text { rating method. }\end{array}$ \\
\hline
\end{tabular}


Table 3 Continued

\begin{tabular}{|c|c|c|c|c|c|}
\hline \multirow{3}{*}{ Student Perceptions } & $\begin{array}{l}\text { D. R. Bacon, K. A. } \\
\text { Stewart \& } \\
\text { S. W. Silver [14] }\end{array}$ & 1999 & $\begin{array}{l}1^{\text {st }} \text { year MBA students at a Midwest } \\
\text { university (USA) }\end{array}$ & $\begin{array}{l}\text { Attitudinal survey and statistical } \\
\text { analysis to measure students' } \\
\text { perception of traditional peer } \\
\text { review instruments }\end{array}$ & $\begin{array}{l}\text { The use of traditional (confidential, } \\
\text { end-of-term only) peer reviews was } \\
\text { negatively correlated with best team } \\
\text { experiences. }\end{array}$ \\
\hline & $\begin{array}{l}\text { T. H. Wagar\& W. R. } \\
\text { Carroll [53] }\end{array}$ & 2012 & $\begin{array}{l}\text { Undergraduate university business } \\
\text { students (Canada) }\end{array}$ & $\begin{array}{l}\text { Attitudinal survey and statistical } \\
\text { analysis to assess student } \\
\text { preferences among four peer } \\
\text { evaluation approaches }\end{array}$ & $\begin{array}{l}\text { Students preferred confidential questionnaires } \\
\text { to assess peer performance. } \\
\text { Confidential questionnaires were deemed the } \\
\text { fairest and best method for assessing } \\
\text { individual contribution. }\end{array}$ \\
\hline & M. R. Fellenz[70] & 2006 & $\begin{array}{l}\text { Senior undergraduate university students } \\
\text { enrolled in a business strategy course } \\
\text { (Ireland) }\end{array}$ & $\begin{array}{l}\text { Attitudinal survey and statistical } \\
\text { analysis to measure students' } \\
\text { reaction to the use of Groupwork } \\
\text { Peer-Evaluation Protocol (GPEP) }\end{array}$ & $\begin{array}{l}\text { Students perceived GPEP (a fixed-pie system) } \\
\text { positively and believed it contributed to } \\
\text { fairness. } \\
\text { GPEP had interrater reliability and stability } \\
\text { over time. }\end{array}$ \\
\hline
\end{tabular}


While students do not regard these reviews as useful for themselves or their teams, they acknowledge their value to the professor as an aid in assessing individual contributions [50]. Best practices include establishing a rubric, sharing it with students at the onset, and training them how to use it [51]. Typically, these rubrics include feedback on communication skills, individual contributions, preparation, and collaboration [46]. Peer assessments taken intermittently throughout the project serve as formative input and reduce social loafing, allow students to correct behavior, and improve learning along the way $[25,43,51$, 52]. Students perceive confidential questionnaires to be the fairest and best method of assessing individual contributions [53].

A range of peer review instruments exists. Research is sparse on the relative advantages of or student preferences for each. Baker [46] tested the reliability and validity between a short, four-question instrument, which covered preparation, communication, contributions and cooperation, and a long-form questionnaire, which went into extensive detail on nine attributes among them: commitment, leadership, conflict resolution and group facilitation skills. Both the long form and the short form proved effective, with students preferring the short form for ease of use, despite the fact that it offered slightly less detailed feedback for formative purposes.

\subsection{Discussion on Team Assessments}

The issue of free-riding or social loafing jeopardizes the success of group projects not only for the professor but also for many students. Prior experience with these issues can prevent faculty from including group projects in their courses, which works counter to the desires of employers to have practice-ready workers who know how to collaborate in a team.

Peer ratings are essential to team success. The data clearly indicate the value these assessments offer. They allow the professor to determine individual contributions and ferret out free riders. In designing a peer assessment instrument, an analytical tool, which uses Likert-style ratings works best [55]. Professors should consider the student learning outcomes that lie at the base of the group project and then design the instrument accordingly. For example, if a goal of the project is for students to demonstrate creative problem solving, the assessment instrument should ask for students to rate each other on this attribute. Similarly, if the project aims to develop students' soft skills a peer questionnaire might include: the ability to collaborate, the ability to communicate, the degree to which individual students participate and contribute, and the effort students put into preparing for and attending team meetings. As Baker [46] demonstrated, faculty should err on the side of simplicity because a short questionnaire outweighs the value of detailed feedback.

After designing the assessment tool, the research shows the importance of sharing it with students and training them how to use it [48]. Training need not take long or create angst for professors. Providing students with a few simple guidelines on how to use the assessment tool pays dividends in terms of the usefulness and value of collecting this kind of data. A short all-class discussion can prevent rater errors such as leniency bias or severity error. Professors need only cover what each point on the rating scale means and give a few examples to clarify. In addition, an overview of the performance dimensions is advised. In this type of review, would-be raters establish a common understanding of specific behaviors to look for in evaluating their peers [51]. Without taking the time to provide this type of guidance, professors risk the value inherent in peer assessments.

\subsection{Charters and Electronic Tools}

Research shows team charters enhance student satisfaction and increase output quality (see Table 4). As a review of the five studies in this synthesis on team charters demonstrates, charters improve students' perceptions of team effectiveness, improve task cohesion and participation, and add to student satisfaction with group work [31, 55-57]. 
Table 4. Charters and Electronic Tools

\begin{tabular}{|c|c|c|c|c|c|}
\hline Sub-Theme & Author(s) & Publication Date & Context & Research Method/Question & Findings \\
\hline \multirow{5}{*}{ Charters } & $\begin{array}{l}\text { P. Hunsaker } \\
\text { C. Pavett\& } \\
\text { J. Hunsaker [31] }\end{array}$ & 2011 & $\begin{array}{l}\text { Business management students at } \\
\text { a private college (USA) }\end{array}$ & $\begin{array}{l}\text { Attitudinal survey and statistical } \\
\text { analysis to measure student perceptions } \\
\text { on team charters }\end{array}$ & $\begin{array}{l}\text { Students felt team charters improved team } \\
\text { dynamics, satisfaction and productivity. } \\
\text { Students indicated charters increased team } \\
\text { member participation. }\end{array}$ \\
\hline & $\begin{array}{l}\text { J. R. Aaron, } \\
\text { W.C. McDowell } \\
\& \\
\text { A. O. Herdman[56] }\end{array}$ & 2014 & $\begin{array}{l}\text { Undergraduate business students } \\
\text { at a Southwest university (USA) }\end{array}$ & $\begin{array}{l}\text { Statistical analysis comparing student } \\
\text { satisfaction among teams using charters } \\
\text { with/without teacher instruction; } \\
\text { with/without examples }\end{array}$ & $\begin{array}{l}\text { Teacher instruction on charter significantly } \\
\text { improved students' perception of team } \\
\text { effectiveness. } \\
\text { Teams receiving charter examples but no } \\
\text { instruction had higher perceived performance } \\
\text { compared to control (no charter). } \\
\text { No significant difference between groups with } \\
\text { instruction and team charter example. }\end{array}$ \\
\hline & $\begin{array}{l}\text { S. H. Courtright } \\
\text { B. McCormick, S. Mistry \& } \\
\text { J. Want [57] }\end{array}$ & 2017 & $\begin{array}{l}\text { Undergraduate management } \\
\text { students at a Midwest university } \\
\text { (USA) }\end{array}$ & $\begin{array}{l}\text { Attitudinal survey and statistical } \\
\text { analysis of team charter quality, team } \\
\text { conscientiousness, task cohesion and } \\
\text { team performance }\end{array}$ & $\begin{array}{l}\text { Team charters were not universally beneficial, } \\
\text { teams high in conscientiousness (dependable) } \\
\text { did not benefit from them. } \\
\text { A strong team charter improved performance } \\
\text { of teams with low conscientiousness. }\end{array}$ \\
\hline & $\begin{array}{l}\text { J. E. Mathieu. \& T. E. Rapp, } \\
\text { [55] }\end{array}$ & 2009 & $\begin{array}{l}\text { MBA students at a Northeast } \\
\text { university (USA) }\end{array}$ & $\begin{array}{l}\text { Statistical analysis to evaluate team } \\
\text { charter use in the context of a } \\
\text { multi-round computer simulation } \\
\text { assignment }\end{array}$ & $\begin{array}{l}\text { High quality charters benefited teams with poor } \\
\text { strategies only in the short term, not in the long } \\
\text { run. } \\
\text { There was a three-way interaction between } \\
\text { quality of charter, the quality of the team's } \\
\text { strategies and team longevity. }\end{array}$ \\
\hline & $\begin{array}{l}\text { T. E. Sverdrup \& V. } \\
\text { Schei[58] }\end{array}$ & 2015 & $\begin{array}{l}\text { Agri-business work teams in } \\
\text { Norway }\end{array}$ & $\begin{array}{l}\text { Embedded case study comparing } \\
\text { implicit contracts and explicit contracts } \\
\text { for group regulation and results }\end{array}$ & $\begin{array}{l}\text { Teams using explicit team charters functioned } \\
\text { better (work quality) with fewer breaches } \\
\text { (work effort) than teams with implicit group } \\
\text { process agreements. }\end{array}$ \\
\hline \multirow{3}{*}{ Diaries } & $\begin{array}{l}\text { J. Ballantine \& P. M. Larres, } \\
\text { [59] }\end{array}$ & 2006 & $\begin{array}{lr}\text { Undergraduate } & \text { university } \\
\text { advanced accounting } & \text { students } \\
\text { (United Kingdom) } & \end{array}$ & $\begin{array}{l}\text { Attitudinal survey and statistical } \\
\text { analysis to determine the effect of } \\
\text { learning logs on social loafing }\end{array}$ & $\begin{array}{l}\text { Students felt neither individual learning logs } \\
\text { nor group logs reduced social loafing. } \\
\text { No difference between "more able" and "less } \\
\text { able" accounting students. }\end{array}$ \\
\hline & C. J. Dommeyer[60] & 2007 & $\begin{array}{l}\text { Undergraduate market research } \\
\text { students at a Western university } \\
\text { (USA) }\end{array}$ & $\begin{array}{l}\text { Attitudinal survey and statistical } \\
\text { analysis to determine student } \\
\text { perceptions of individual diaries and } \\
\text { group diaries }\end{array}$ & $\begin{array}{l}\text { Students reported neither the individual diary } \\
\text { nor the group diary increased their contribution } \\
\text { to the project. } \\
\text { Students did not understand the purpose of the } \\
\text { diaries and felt both types were too time } \\
\text { consuming }\end{array}$ \\
\hline & G. Harris \& D. Bristow [61] & 2016 & $\begin{array}{l}\text { Undergraduate business students } \\
\text { in a public university (USA) }\end{array}$ & $\begin{array}{l}\text { Textual and content analysis of weekly } \\
\text { reflective journals kept by students }\end{array}$ & $\begin{array}{l}\text { Journaling helped students learn on two levels: } \\
\text { (1) course content; (2) how to work effectively } \\
\text { in groups }\end{array}$ \\
\hline
\end{tabular}


Table 4 Continued

\begin{tabular}{|c|c|c|c|c|c|}
\hline \multirow{5}{*}{ eTools } & $\begin{array}{l}\text { M. L. Loughry, M. W. } \\
\text { Ohland\& F. J. Woehr[63] }\end{array}$ & 2014 & $\begin{array}{l}\text { Students in AACSB accredited } \\
\text { business schools (USA) }\end{array}$ & Product review of CATME system & $\begin{array}{l}\text { CATME adequately delivered team training } \\
\text { and helped students manage team processes. }\end{array}$ \\
\hline & $\begin{array}{l}\text { M. H. Murray \& B. } \\
\text { Lonne[27] }\end{array}$ & 2006 & $\begin{array}{l}\text { Undergraduate university students } \\
\text { across disciplines (Australia) }\end{array}$ & $\begin{array}{l}\text { Attitudinal survey and statistical } \\
\text { analysis of student satisfaction with } \\
\text { TeamWorker, a proprietary team } \\
\text { management software }\end{array}$ & $\begin{array}{l}\text { Use of the software did not reduce social } \\
\text { loafing or ineffective team meetings. } \\
\text { Software assisted students in handling team } \\
\text { dysfunction. }\end{array}$ \\
\hline & $\begin{array}{l}\text { I. G. Arkilic, } \\
\text { S. Peker\& } \\
\text { M. E. Uyar[66] }\end{array}$ & 2013 & $\begin{array}{l}\text { Undergraduate students in arts and } \\
\text { sciences at a technical university } \\
\text { (Turkey) }\end{array}$ & $\begin{array}{l}\text { Statistical analysis of students' } \\
\text { perception of electronic communication } \\
\text { devices used in group project work }\end{array}$ & $\begin{array}{l}\text { Collaborative document management system, } \\
\text { video conferencing, shared directories and } \\
\text { instant messaging were useful. } \\
\text { Voicemail and shared whiteboard were not } \\
\text { useful. }\end{array}$ \\
\hline & $\begin{array}{l}\text { Y. Cleary \& } \\
\text { A. Marcus-Quinn, [67] }\end{array}$ & 2008 & $\begin{array}{l}\text { Undergraduate communication } \\
\text { students at a university in Ireland }\end{array}$ & $\begin{array}{l}\text { Qualitative study of student feedback } \\
\text { on group project management tools }\end{array}$ & $\begin{array}{l}\text { Students were reluctant to use the tools (chat, } \\
\text { file sharing). } \\
\text { Among students using the tools, comments } \\
\text { were generally positive. }\end{array}$ \\
\hline & $\begin{array}{l}\text { S. Kai-Wai Chu\& } \\
\text { D.M. Kennedy [68] }\end{array}$ & 2010 & $\begin{array}{l}\text { Undergraduate university } \\
\text { management information students } \\
\text { (Hong Kong) }\end{array}$ & $\begin{array}{l}\text { Attitudinal survey and statistical } \\
\text { analysis to assess the effect of Media } \\
\text { Wiki and Google Docs in facilitating } \\
\text { group projects }\end{array}$ & $\begin{array}{l}\text { Both tools received high ratings. Users felt both } \\
\text { were easy to use and effective. } \\
\text { A slight advantage was perceived for Media } \\
\text { Wiki, although } \mathrm{N} \text { is small. }\end{array}$ \\
\hline
\end{tabular}


While some teams form implicit agreements on codes of conduct and work processes, these informal agreements prove inferior to written team charters [58]. However, to receive maximum benefit from the use of these instruments, students need instruction on how to develop a strong charter or at the very least they need examples of well-written ones [56]. The work of Court right, et. al. [57] showed when teams are comprised of individuals that are highly task focused and dependable, charters are less useful; however, in the absence of these types of team members, charters contribute to an improvement in team performance. In addition, high quality charters offer early benefits to teams which struggle to form a workable project strategy [55].

Conversely, asking teams or individuals to keep diaries or learning logs in which students reflect on team processes and experiences, show little benefit $[59,60]$. Students report neither the keeping of a group learning log nor an individual diary contributes to a reduction in social loafing [59]. In the same vein, these tools failed to increase students' contributions to project work, and increased students' concerns about monitoring and surveillance [60]. Only Harris \& Britow [61] demonstrated a benefit to diaries, which enhanced students' understanding of how group processes contribute to the development of new product ideas.

The advent of learning management systems (LMS) offers faculty promising new tools for regulating group work [62]. LMS include all-in-one packages to assist with team formation, communication, peer assessments, and document management [27, 63]. Some universities adopt electronic peer ratings systems for use across all course offerings, which standardizes the process, improves consistency and rater proficiency [64]. Regardless of the system chosen, faculty needs to train students how to use these tools to assure success [65].

The digital age offers students a number of project management tools and other software to support students working in teams. Evaluating the value of these devices falls along two lines of inquiry. First, how do students feel about using such digital tools and secondly, are these mechanisms effective in improving group processes or team performance? The available research in this area continues to emerge but presently remains sparse. Arkilic, Peker \& Uyar[66] found students ascribed value to some tools more than others. For example, students found document management systems, video conferencing and instant messaging to be useful but felt shared whiteboards and voicemail offered little value. These types of aids may require an adoption curve, but once students feel confident about how to apply these tools, their attitudes toward them are generally positive [67]. Among studies looking at specific software, Google Docs, Media Wiki and CATME all received high ratings from students $[63,68]$. While these tools assist with team processes such as sharing documents, to date, the research shows little impact on team performance or on mitigating issues such as social loafing [27].

\subsection{Discussion on Charters and Electronic Tools}

Finding time in a lesson plan to incorporate team training and other group project interventions may pose a challenge for faculty. However, group projects often comprise a significant proportion of a student's grade and may serve as a final summative assessment in some courses. For this reason, it is important for faculty to find ways to incorporate the necessary steps to assure team success. Given the research on team charters, faculty can take a few simple steps to incorporate this tool into group projects. Introducing the instrument at the beginning of the project works well. Taking a few minutes to demonstrate how to complete the charter and then giving students time in class to work on it can be helpful. Completing the charter as a homework assignment is also an option. In the absence of specific training, research also suggests that providing students with an exemplar of a strong, well-written charter reaps similar benefits [56]. Successful charters include a mission statement (why the team exists); a vision (desired outcome); behavior expectations; evaluation methods; and, consequences for failure to adhere to agreements [31].

Today's students feel comfortable with digital technology, sometimes more so than their professors. Regardless, professors should encourage students' use of project management software and digital communication tools. Early research in this area shows promise in enhancing the effectiveness of group projects.

While the adoption and use of electronic aids such as Google Docs or Media Wiki varies by university, deploying tools like these helps with document sharing and communication. Typically, universities have procured learning software on an enterprise basis offering all students the same access to document sharing platforms, instant messaging or video conferencing. It is recommended that professors make students aware of the resources available to them, perhaps providing a list of available resources and their intended resources. Professors may call on experts from departments such as academic technology or similar support areas to offer students demonstrations and training to make sure students feel confident in using these tools. Summary and Implications for Practice

In business, organizations rate team performance on the basis of goal attainment and outcomes. In an academic setting, faculty need to consider two additional goals, the desire to teach students how to collaborate and the need for them to master the course content [40]. To help faculty achieve these goals and on the basis of the above research synthesis and discussions, a summary of ten recommendations emerge for faculty to consider. These go beyond sink or swim and provide proven methods and best practices to not only improve student satisfaction when 
working in teams but also increase the likelihood they learn the skills needed to succeed on the job.

1. Use a hybrid approach to team selection. Students select a team member to work with. Faculty assembles teams by combining pairs of students to assure each team has a balance of students with leadership skills, domain knowledge and self-efficacy.

2. Keep teams small (4-5 students per team)

3. Include team training at the onset

4. Have students develop a team charter

5. Stay involved throughout the project

6. Provide additional training along the way

7. Use peer review evaluations at the end of the project

8. Use peer evaluations formatively (intermittently at milestones throughout the project)

9. Provide rater training

10. Maximize the use of electronic aids

\section{Limitations of the Study}

While this study includes a larger sampling of research articles than others of its kind, it is nevertheless limited. The topic of group projects in higher education is widely studied and research abounds in this area. While the articles chosen for this review earned their place in this synthesis, others logically exist that could have been included. In addition, some of the research papers reviewed here have their own limitations. For example, while a hybrid approach to assigning students to teams which are balanced not only for self-selected pairs but also for domain knowledge, leadership skills and self-efficacy, the research on this topic offer little in terms of understanding how to assess these attributes, especially in cases where little is known about the student's background. Similarly, the research on the use of eTools and project management software programs is limited, partially because these tools are new and the market is fragmented. Last, this synthesis offers a set of ten recommendations for consideration. As a set, these recommendations have not been tested and need to be implemented and studied to confirm their value (as a set) in the classroom.

\section{Conclusions and Future Research}

The works reviewed here and the recommendations provide a starting point for faculty who rely on group projects as part of their curricula. Based on more than 46 empirical studies, these recommendations stem from a robust dataset triangulated across time, by different methodologies, academic settings and sample populations. The resulting synthesis offers a strong foundation on which future research can build. Little research exists on the use of electronic tools used in group work. The few available studies on this topic focus on student usability rather than the effect these tools have on output or student achievement. Similarly, only one study in this synthesis evaluated incentives awarded to group leaders and while this study offered promising results, future research is needed to explore this topic further. Lastly, given the importance of upfront team instruction, research to assess the relative value of various methods and frequency of team building interventions would also be welcome. As long as employers continue to seek team-building skills, it is incumbent on university researchers to test the best practices for turning out practice-ready business graduates.

\section{REFERENCES}

[1] J. Casner-Lotto \& L. Barrington. Are They Really Ready to Work? Employers' Perspectives on the Basic Knowledge and Applied Skills of New Entrants to the 21st Century U.S. Workforce. The Conference Board, 2006.

[2] F. F. Ghannadian, F. F. What Employers Want, What We Teach. BizEd AACSB International. Online available from http://bized.aacsb.edu/articles/2013/03/what-employers-wa nt-what-we-teach, 2014.

[3] Hart Research and Associates Falling short. College learning and career success. Association of American Colleges and Universities, 2015.

[4] A. C. Edmonson, \&I. M. Nembhard. Product Development and Learning in Project Teams: The Challenges and the Benefits. Journal of Product Innovation Management, Vol. 26, No.2, 123-138, 2009.

[5] S. K. Horwitz, \&I. B. Horwitz, I. B. The Effects of Team Diversity on Team Outcomes: A Meta-Analytic Review of Team Demography. Journal of Management, Vol. 33 No.6, 987-1015, 2007.

[6] S. Vivas-López. Talent Management and Teamwork Interaction: Evidence in Large Spanish Companies. International Journal of Business, Vol. 19, No.1, 30-43, 2014.

[7] W. Bennis, \& J. O'Toole. How Business Schools Lost Their Way. Harvard Business Review, Vol. 8, No. 5, 96-104, 2005.

[8] O. Varella, M. Burke, \&N. Michel. The Development of Managerial Skills in MBA Programs: A Reconsideration of Learning Goals and Assessment Procedures. Journal of Management Development, Vol. 32, No. 4, 435-452, 2013.

[9] S. Bailey, L. K Barber \&A. J. Ferguson. Promoting Perceived Benefits of Group Projects: The Role of Instructor Contributions and Intragroup Processes. Teaching of Psychology, Vol. 42, No. 2, 179-183, 2015.

[10] J. Cumming. Student-initiated Group Management Strategies for More Effective and Enjoyable Group Work Experiences. Journal of Hospitality, Leisure, Sports and Tourism Education, Vol. 9, No. 2, 31-45, 2010.

[11] B. A. Easter, \&B. Evans, B. Student Views of Class Projects as Learning Experiences. Schole: A Journal of Leisure 
Studies and Recreation Education, Vol. 29, No. 2, 25, 2014.

[12] J. R. Tombaugh, \& C. O. Mayfield. Teams on Teams: Using Advice from Peers to Create a More Effective Atudent Experience. Academy of Educational Leadership Journal, Vol. 18, No. 4, 69-83, 2014.

[13] R. J. Volkema. Designing Effective Projects: Decision Options for Maximizing Learning and Project Success. Journal of Management Education, Vol. 34, No. 4, 527-550, 2010.

[14] D. R. Bacon, K. A. Stewart \& W. S. Silver. Lessons from the Best and Worst Student Team Experiences: How a Teacher Can Make a Difference. Journal of Management Education, Vol. 23, No. 5, 467-488, 1999.

[15] K. J. Chapman, M. L. Meuter, D. Toy \& L. K. Wright. Are Student Groups Dysfunctional? Perspectives from Both Sides of the Classroom. Journal of Marketing Education, Vol. 32, No. 1, 39-49, 2010.

[16] D. Hall, \& S. Buzwell. The Problem of Free-riding in Group Projects: Looking beyond Social Loafing as Reason for Non-contribution. Active Learning in Higher Education, Vol. 14, No. 1, 37-49, 2012.

[17] J.W. Murray. I hate/don’t Hate/still Hate Group Projects! A Tripartite Ethical Framework for Enhancing Student Collaboration. Cogent Education, Vol. 4, No. 1, 1-22, 2017.

[18] M. G. Sembiring. Student Satisfaction and Persistence: Imperative Features for Retention in Open and Distance Learning. Asian Association of Open Universities Journal, Vol. 10, No.1, 1-11, 2015.

[19] R. S. Hansen. Benefits and Problems with Student Teams: Suggestions for Improving Team Projects. Journal of Education for Business, Vol. 82, No. 1, 11-19, 2006.

[20] M. McKendall. Teaching Groups to Become Teams. Journal of Education for Business, Vol. 75, No. 5, 277-282, 2000.

[21] G. Vik, G. Doing More to Teach Teamwork Than Telling Students to Sink or Swim. Business Communication Quarterly, Vol. 64, No. 4, 112-119, 2001.

[22] H. Synder. Literature Review as a Research Methodology: An Overview and Guidelines. Journal of Business Research, Vol. 104,333-339, 2019.

[23] M. E. Burbach, G. S. Matkin, K. M. Gambrell, \&H. E. Harding. The Impact of Preparing Faculty in the Effective Use of Student Teams. College Student Journal, Vol. 44, No. 3, 752-761, 2010.

[24] K. J. Chapman \& S. Van Auken. Creating Positive Group Project Experiences: An Examination of the Role of the Instructor on Students' Perceptions of Group Projects. Journal of Marketing Education, Vol. 23, 117-127, 2001

[25] E. Kapp. Improving Student Teamwork in a Collaborative Project-based Course. College Teaching, Vol. 57, No. 3, 139-143, 2009.

[26] P. Navarro. The MBA Core Curricula of Top-Ranked U.S. Business Schools: A Study in Failure. Academy of Management Learning \& Education, Vol. 7, No. 1, 102-123, 2008.

[27] M. H. Murray \& B. Lonne. An Innovative Use of the Web to
Build Graduate Team Skills. Teaching in Higher Learning, Vol. 11, No. 1, 63-77, 2006.

[28] J. Cumming. Student-initiated Group Management Strategies for More Effective and Enjoyable Group Work Experiences. Journal of Hospitality, Leisure, Sports and Tourism Education, Vol. 9, No. 2, 31-45, 2010.

[29] L. Riebe, D. Roepen, B. Santarelli, \& G. Marchioro. Teamwork: Effectively Teaching an Employability Skill. Education Training, Vol. 52, No.6/7, 528-539, 2010.

[30] B. Scott-Ladd \& C. C. A. Chan. Using Action Research to Teach Students to Manage Team Learning and Improve Teamwork Satisfaction. Active Learning in Higher Education, Vol. 9, No. 3, 231-248, 2008.

[31] P. Hunsaker, C. Pavett \& J. Hunsaker. Increasing Student-learning Team Effectiveness with Team Charters. Journal of Education for Business, Vol. 86, No. 3, 127-139, 2011.

[32] A. L. Parsons, \& E. Lepkowska-White. Group Projects Using Clients Versus Not Using Clients: Do Students Perceive Any Differences? Journal of Marketing Education, Vol. 31, No.2, 154-159, 2009.

[33] C. M. Wood. The Effects of Creating Psychological Ownership among Students in Group Projects. Journal of Marketing Education, Vol. 25, No. 3, 240-249, 2003.

[34] C. J. Ferrante, S. G. Green \& W.R. Forster. Getting More Out of Team Projects: Incentivizing Leadership to Enhance Performance. Journal of Management Education, Vol. 30, No. 6, 788-797, 2006.

[35] R. Seethamraju \& M. Borman. Influence of Group Formation Choices on Academic Performance. Assessment \& Evaluation in Higher Education, Vol. 34, No. 1, 31-40, 2009.

[36] S. Hilton \& F. Phillips. Instructor-assigned and Student-selected Groups: A View from Inside. Issues in Accounting Education, Vol. 25, No. 1, 15-33, 2010.

[37] C. Dyball, M. A. Reid, P. Ross \& H. Schoch. Evaluating Assessed Group-work in a Second-year Management Accounting Subject. Accounting Education, Vol. 16, No. 2, $145-162,2007$

[38] J. Van Der Laan Smith \& R. M. Spindle. The Impact of Group Formation in a Cooperative Learning Environment. Journal of Accounting Education, Vol. 25, No. 4, 153-167, 2007.

[39] S. Wang \& S. S. J. Lin. The Effects of Group Composition on Self-efficacy and Collective Efficacy on Computer-supported Collaborative Learning. Computers in Human Behavior, Vol. 23, 2256-2268, 2007.

[40] N. M. Schullery \& S. E. Schullery. Are Heterogeneous or Homogeneous Groups More Beneficial to Students? Journal of Management Education, Vol. 30, No. 4, 542-556, 2006.

[41] M. Huxham \& R. Land. Assigning Students in Group Work Projects. Can We Do Better Than Random? Innovations in Education and Training International, Vol. 37, No. 1, 17-22, 2000.

[42] A. C. North, P. A. Linley \& D. J. Hargreaves. Social Loafing 
in a Co-operative Classroom Task. Educational Psychology, Vol. 20, No. 4 389-392, 2000.

[43] P. Aggarwal \& C. L. O'Brien. Social Loafing on Group Projects: Structural Antecedents and Effect on Student Satisfaction. Journal of Marketing Education, Vol. 30, No.3, 255-264, 2008.

[44] M. Sharma\& A. Ghosh. Does Team Size Matter? A Study of the Impact of Team Size on the Transactive Memory System and Performance of IT Sector Teams. South Asian Journal of Management, Vol. 14, No.4, 96-115, 2007.

[45] S. Mahenthiran \& P. J. Rouse. The Impact of Group Selection on Student Performance and Satisfaction. International Journal of Education Management, Vol. 14, No. 6, 255-265, 2000.

[46] D. Baker. Peer Assessment in Small Groups: A Comparison of Methods. Journal of Management Education, Vol. 32, No. 2, 183-209, 2008

[47] D. Bamford, K. Karjalainen \& E. Jenavs. An Evaluation of Problem-based Assessment in Teaching Operations Management. International Journal of Operations \& Production Management, Vol. 32, No. 12, 1493-1514, 2012.

[48] E. Gammie \& M. Matson. Group Assessment at Final Degree Level: An Evaluation. Accounting Education: An International Journal, Vol. 16, No. 2, 185-206, 2005.

[49] B. Zhang, L. Johnson \&B. K. Gulsen. Assessing the Reliability of Self- and Peer Rating in Student Group Work. Assessment \& Education in Higher Education, Vol. 33, No.3, 329-340, 2008.

[50] P. D. Rafferty. Group Work in the MBA Classroom: Improving Pedagogical Practice and Maximizing Positive Outcomes with Part-time MBA Students. Journal of Management Education Vol. 37, No.5 623-650, 2013.

[51] G. May. The Effect of Rater Training on Reducing Social Style Bias in Peer Evaluation. Business Communication Quarterly, Vol.71, No.3, 297-313, 2008.

[52] C. M. Brooks \& J. L. Ammons. Free Riding in Group Projects and the Effects of Timing, Frequency, and Specificity of Criteria in Peer Assessments. Journal of Education for Business, Vol. 78, No. 5, 268-272, 2003.

[53] T. Wagar \& W. Carroll. Examining Student Preferences of Group Work Evaluation Approaches: Evidence from Business Management Undergraduate Students. Journal of Education for Business, Vol. 87, No.6, 358-362, 2012.

[54] B. Zhang \& M. Ohland. How to Assign Individualized Scores on a Group Project: An Empirical Evaluation. Applied Measurement in Education, Vo. 22, No.3, 290-308, 2009.

[55] J. E. Mathieu \& T.L. Rapp. Laying the Foundation for Successful Team Performance Trajectories: The Roles of Team Charters and Performance Strategies. Journal of Applied Psychology, Vol. 94, No.1, 90-103, 2009.

[56] J. R. Aaron, W. C. Mcdowell \&, A. O. Herdman. The Effects of a Team Charter on Student Team Behaviors. Journal of Education for Business, Vol. 89, No. 2, 90-97, 2014.

[57] S. H. Courtright, B. W. McCormick, S. Mistry \& J. Wang.
Quality Charters or Quality Members? A Control Theory Perspective on Team Charters and Team Performance. Journal of Applied Psychology. Vol. 102, No. 10, 1462-1470, 2017.

[58] T. E. Sverdrup \& V. Schei. "Cut Me Some Slack": The Psychological Contracts as a Foundation for Understanding Team Charters. The Journal of Applied Behavioral Science, Vol. 51, No.4, 451-478, 2015.

[59] J. Ballantine \&P. M. Larres. Final Year Accounting Undergraduates' Attitudes to Group Assessment and the Role of Learning Logs. Accounting Education, Vol. 16, No. 2, 63-83, 2007.

[60] C. J. Dommeyer. Using the Diary Method to Deal with Social Loafers on the Group Project: Its Effects on Peer Evaluations, Group Behavior, and Attitudes. Journal of Marketing Education, Vol. 29, No. 2, 175-188, 2007.

[61] G. Harris \&D. Bristow. The Role of Group Regulation in Student Groups; A Pedagogical Exploration. Journal of Business Education and Scholarship of Teaching, Vol. 10, No. 2, 47-59, 2016

[62] S. Järvelä, H. Järvenoja, J. Malmberg, \& A. F. Hadwin. Exploring Socially Shared Regulation in the Context of Collaboration. Journal of Cognitive Education and Psychology, Vol. 12, No.3, 267-286, 2013.

[63] M. L. Loughry, M. W. Ohland \& D. J. Woehr. Assessing Teamwork Skills for Assurance of Learning Using CATME Team Tools. Journal of Marketing Education, Vol. 36, No. 1, 5-19, 2014.

[64] S. Brutus \& M. B. Donia. Improving Effectiveness of Students in Groups with a Centralized Peer Evaluation System. Academy of Management Learning \& Education, Vol. 9, No.1, 652-662, 2010.

[65] B. Perron, B. Reducing Social Loafing in Group-Based Projects. College Teaching, Vol. 59, No. 4, 163-164, 2011.

[66] I. G. Arkilic, S. Peker \& M. E. Uyar. Students' Preferences of Communication Tools for Group Projects in a Computer-supported Collaborative Learning Environment: A Survey. Procedia - Social and Behavioral Sciences, Vol. 83, 1121-1125, 2013.

[67] Y. Cleary \& A. Marcus-Quinn. Using a Virtual Learning Environment to Manage Group Projects: A Case Study. International Journal on ELearning, Vol., No. 4, 603-621, 2008.

[68] S. Kai-Wai Chu \& D. M. Kennedy. Using Online Collaborative Tools for Groups to Co-construct Knowledge. Online Information Review, Vol. 35, No. 4 581-597, 2011.

[69] M. L. Connerley \& F. A. Mael. The Importance and Invasiveness of Student Team Selection Criteria. Journal of Management Education, Vol. 25, No. 5, 471-494, 2001.

[70] M. R. Fellenz. Toward Fairness in Assessing Student Group work: A Protocol for Peer Evaluation of Individual Contributions. Journal of Management Education, Vol. 30, No. 4, 570-591, 2006. 